International Research Journal of Management, IT \& Social Sciences
Available online at https://sloap.org/journals/index.php/irjmis/
Vol. 9 No. 1, January 2022, pages: 79-89
ISSN: 2395-7492
https://doi.org/10.21744/irjmis.v9n1.2006

\title{
The Role of Brand Image and Customer Commitment in Mediating Service Quality Towards Customer Loyalty
}

\author{
Anak Agung Bagus Putra Mahatama ${ }^{a}$
}

Made Wardana $^{\text {b }}$

Article history:

Submitted: 09 October 2021

Revised: 27 November 2021

Accepted: 15 December 2021

\section{Keywords:}

brand image;

customer commitment;

customer loyalty;

service quality;

village credit institution;

\begin{abstract}
The purpose of this study is to explain the role of brand image and customer commitment in mediating the effect of service quality on customer loyalty. The population in this study is customers at Kedonganan Village Credit Institution. The purposive sampling method has been used with 130 respondents included. Questionnaires were distributed and the result are analyzed using PLS (Partial Least Square) technique. The results of this study indicate that service quality has a positive and significant effect on brand image, customer commitment, and customer loyalty at Kedonganan Village Credit Institution. There was a significant role of brand image and customer commitment in mediating the effect of service quality on customer loyalty at Kedonganan Village Credit Institution. In order to improve brand image and customer commitment, it is hoped that Kedonganan Village Credit Institution will be able to provide faster service, attractive promotions, and technology improvement to encourage customer loyalty.
\end{abstract}

International research journal of management, IT and social sciences (C) 2022. This is an open access article under the CC BY-NC-ND license (https://creativecommons.org/licenses/by-nc-nd/4.0/).

Corresponding author:

Anak Agung Bagus Putra Mahatama,

Faculty of Economics and Business, Udayana University, Denpasar, Indonesia.

Email address: mahatama.p@gmail.com

Faculty of Economics and Business, Udayana University, Denpasar, Indonesia

Faculty of Economics and Business, Udayana University, Denpasar, Indonesia 


\section{Introduction}

Economic development in emerging markets such as Indonesia cannot be separated from the role of various parties including the government, business actors, and institutions in the financial sector (Purwaningsih \& Kusuma, 2015). Currently in Indonesia, the type of microfinance sector is very diverse. The Village Credit Institution or known as LPD in Bali is a financial institution belonging to a traditional village (Dewi et al., 2017). This institution was founded in 1985, and in 2017 the number had reached 1,443 LPDs. LPD Kedonganan is one of the LPDs in Badung Regency which is engaged in financial services. In fostering public trust, it is important to improve performance amid fierce business competition. An indication of good performance is an increased value of assets and profits from time to time. Table 1, shows the assets and profits of LPD Kedonganan from the 2016-2019 period.

Table 1

Total assets, percentage of assets, total profits dan percentage of profits of LPD Kedonganan in 2016-2019

\begin{tabular}{lllll}
\hline Year & $\begin{array}{l}\text { Total Assets } \\
(\mathrm{Rp} \mathrm{000)}\end{array}$ & Asset Growth (\%) & $\begin{array}{l}\text { Profits } \\
(\text { Rp000) }\end{array}$ & Profits Growth (\%) \\
\hline 2016 & 136.019 .081 & - & 4.446 .082 & - \\
2017 & 162.478 .762 & 19 & 5.095 .821 & 14 \\
2018 & 210.520 .865 & 29 & 6.154 .196 & 20,7 \\
2019 & 215.780 .910 & 2,38 & 7.004 .560 & 13,8 \\
\hline
\end{tabular}

Source: LPD Kedonganan (2019)

Table 1. shows that the assets of LPD Kedonganan in 2016 amounted to Rp. 136,019,081,000, in 2017 of Rp. $162,478,762,000$ (19 percent) meaning that the assets of LPD Kedonganan in 2017 increased by 10 percent compared to assets in 2016, 2018 which amounted to Rp. 210,520,865,000 (20 percent). means that the assets of the Kedonganan LPD in 2018 have increased by 20 percent compared to 2017 assets, and in 2019 it is Rp. 215,780,910,000 (2.38 percent) meaning that the assets of the Kedonganan LPD in 2018 have increased by 2.38 percent compared to the previous year. Furthermore, the data shows, the profit of the Kedonganan LPD in 2016 was Rp. 4,446,082,000, in 2017 it was Rp. 5,095,821,000 (14 percent), in 2018 was Rp. 6,154,196,000 (20.7 percent) and in 2019 was Rp. $7,004,560,000$ (13,8 percent). In absolute terms, the profits of the LPD Kedonganan have increased but relatively fluctuated. These indicate that LPD Kedonganan is less able to achieve superior performance.

Service quality is one of the factors that influence the level of consumer loyalty (Laemonta \& Padmalia, 2016). Maintaining service quality and consumer loyalty is very much needed by a company engaged in the service sector (Sumertana et al, 2016). Customer commitment is a strong customer desire to maintain a long-term relationship with the company (Tahun et al., 2018). Customer loyalty can maintain and increase sales (Izogo, 2017). Research on the effect of service quality on customer loyalty has been carried out by Kusuma (2018), who found that service quality has no positive and significant effect on customer loyalty. However, different results were obtained by Fikri et al. (2016), which states that service quality has a positive and significant influence on customer loyalty. The research shows that service quality features such as assurance, reliability, physical evidence, and empathy increase customer loyalty to service providers.

Research on variables that mediate service quality on customer loyalty has been conducted by Jahanzeb et al. (2013), which uses the brand image as a mediating variable. In his research, it is stated that a well-managed brand image will produce positive consequences such as customer loyalty. Similar research has been carried out by Fullerton (2014); Parawansa (2018), which use customer commitment as a mediating variable. The higher the quality of service provided, the more the customer's commitment will arise. High customer commitment will encourage consumer loyalty to continue to use the services of the company. Companies also have to consider customer commitment and brand image to encourage customer loyalty, The marketing literature shows customer commitment as stated on Parawansa (2018), and brand image as stated on Levy \& Hino (2016), must be considered as the key to forming customer loyalty. Based on the background above, in an effort to face competition as well as maintain and improve competitive position among microfinance institutions, it is important to conduct further research related to the role of brand image and customer commitment in mediating the effect of service quality on customer loyalty (Kwon \& Lennon, 2009; Nyadzayo \& Khajehzadeh, 2016).

Consumer loyalty reflects a deep commitment to consistently repurchase the chosen product or service in the future (Izogo, 2017). Many factors can affect customer loyalty including service quality (Gede \& Sumaedi, 2013), and 
customer commitment (Rather \& Sharma, 2016). Customer commitment is influenced by service quality (Cater \& Cater, 2010; Fullerton, 2014; Parawansa, 2018). Furthermore, customer commitment as consumer behavior to be loyal to service providers increases customer loyalty (Izogo, 2017). Several studies have found that a strong brand image increases customer loyalty (Chinomona, 2016; Ghani et al., 2018). Based on the description a conceptual framework is developed as shown in Figure 1.

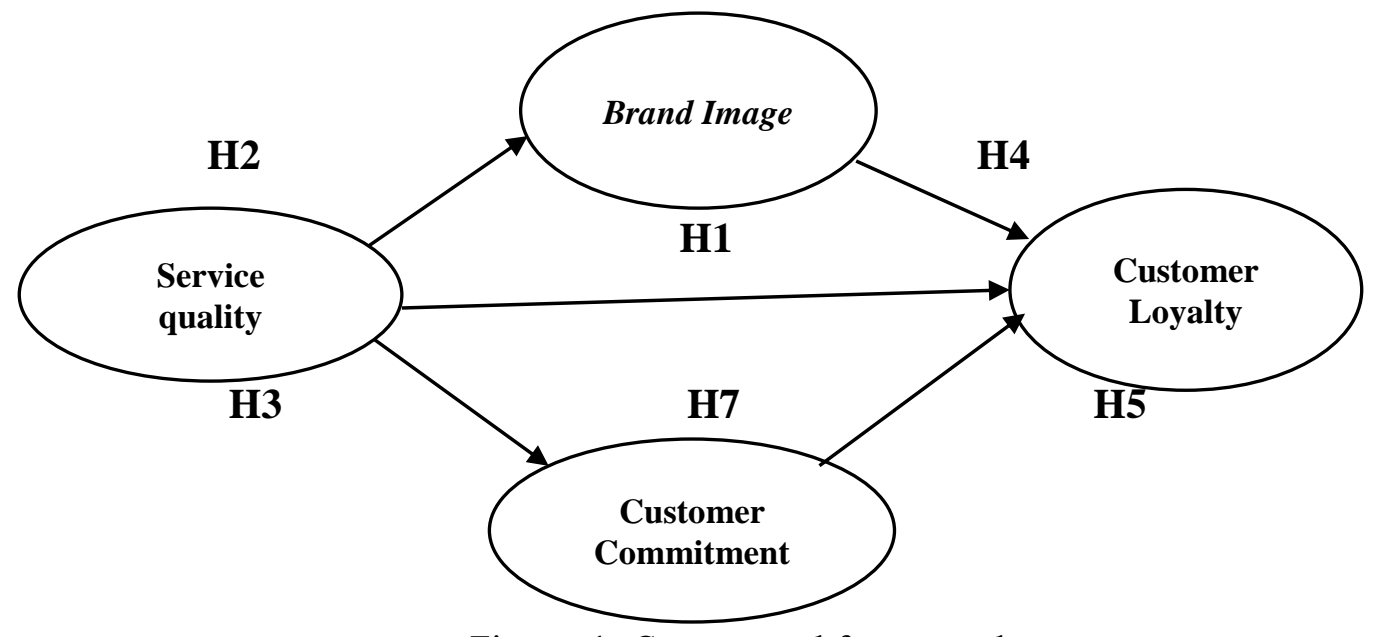

Figure 1. Conceptual framework

Source: Modified from Quach et al. (2016); Parawansa (2018); Izogo (2017); Chinomona (2016)

Service quality is considered a critical success element in the modern service business and a prerequisite for achieving a sustainable competitive advantage Akroush et al. (2015). Empirically, previous research has confirmed that service quality has a positive effect on customer loyalty (Aryani \& Rosinta, 2011; Gede \& Sumaedi, 2013).

\section{H1: Service Quality has a positive and significant effect on Customer Loyalty.}

The company's ability to provide high-quality products is a tool for creating a strong brand image (Mukerjee, 2018). Quality services such as guarantees, physical facilities, and empathy for customers create positive customer perceptions of product brands (Chen, 2015). High service quality improves the company's brand image in the minds of consumers.

\section{H2: Service Quality has a positive and significant effect on Brand Images.}

According to Moorman et al. (1993), customer relationship commitment is the customer's desire to maintain a valuable relationship. Dash et al. (2009), argue that a relationship is valued when the relationship is considered important. The literature explains that service quality has a significant positive effect on customer commitment (Al-Hawari, 2011; Fullerton, 2014).

\section{H3: Service Quality has a positive and significant effect on Customer Commitment}

Brand image as an authentic concept shows the customer's deep commitment to a particular brand that affects customer loyalty to that product brand. Research conducted at shopping malls in South Africa shows that customers tend to be able to form brand images based on their inferences obtained from marketing stimuli, their environment, and experiences (Chinomona, 2016). The results of an empirical study conducted by Saputra (2013), we're able to show evidence that brand image has a positive effect on customer loyalty at BNI 46 bank in Surabaya.

\section{H4: Brand Image has a positive and significant effect on Customer Loyalty}

Loyalty is a deeply held customer commitment to consistently repurchase satisfying products/services in the future (Oliver, 1999). According to Caceres \& Paparoidamis (2007), although commitment and loyalty are related, they are

Mahatama, A. A. B. P., \& Wardana, M. (2022). The role of brand image and customer commitment in mediating service quality towards customer loyalty. International Research Journal of Management, IT and Social Sciences, 9(1), 79-89. https://doi.org/10.21744/irjmis.v9n1.2006 
two different concepts. There is already literature that provides theoretical and empirical support regarding the relationship between commitment and customer loyalty (Izogo, 2017). Providing quality services to maintain customer commitment to remain with the company will increase customer loyalty and market share (Caceres \& Paparoidamis, 2007; Rather \& Sharma, 2016).

\section{H5: Customer commitment has a positive and significant effect on Customer Loyalty.}

Chen (2015), in his research on the effect of brand equity on brand loyalty in the higher education industry in Taiwan, stated that brand image is a dimension of brand equity that has a significant positive effect on consumer attitudes to be loyal to the brand. A brand image consisting of symbolic brand image, functional brand image, and experiential brand image each has a positive and significant effect on consumer loyalty to the brand (Chinomona, 2016). Brand image is a key factor to increase consumer loyalty to a brand. Service quality (SQ) can improve the brand image (Chen et al., 2008). The mediating role of brand image in the relationship between service quality and customer loyalty

\section{H6: Brand Image significantly mediates the effect of Service Quality on Customer Loyalty.}

Research believes that customer loyalty is based on customer commitment (Cater \& Cater, 2010). When customers perceive high service quality, the customer's commitment to voluntarily continue to be with the service provider will be high. Parawansa (2018) on BPR in Makassar found that service quality significantly affects customer commitment. Furthermore, customer commitment raises attitudes for retention and recommends service providers to other parties (Hazra \& Srivastava, 2009).

\section{H7: Customer Commitment significantly mediates the effect of Service Quality to Customer Loyalty}

\section{Materials and Methods}

This study covers the relationship between the constructs variables of service quality, brand image, customer commitment, customer loyalty, and the role of brand image and customer commitment in mediating the effect of service quality on customer loyalty in LPD Kedonganan customers The subjects in this study are people who have become customers and have used their services.

Service quality $(\mathrm{X})$ is the independent variable in this study. Service quality indicators were adapted from research conducted by Parasuraman et al. (1998); Izogo (2017), and divided into several indicators such as Physical Evidence, Assurance, Reliability, Concern, and Responsiveness. Brand image (Y1) is the mediating variable where the indicators were adapted from research conducted by Hamel \& Prahalad (2000), which are Recognition, Attractiveness, Consumer top of minds, and Reputation. Customer commitment (Y2) is also the mediating variable with indicators adopted from Izigo (2017), feelings the emotional attachment to service providers, Partnering with service providers, and being able to be identified by service providers. Customer loyalty (Y) is the dependent variable in this study. Customer Loyalty Indicators were adapted from research conducted by Hazra \& Srivastava (2009), which are continuity using behavior, recommendations to other parties, considered repeat visits, and refuse attractive offers from competing service providers.

The type of data used is qualitative data, an overview of the Village Credit Institution (LPD) of Kedonganan Village. The quantitative data in this study is the age of the respondents, data on the development of the LPD in 2016 - 2019, and respondents' opinions on statements that include service quality, brand image, customer commitment, and customer loyalty. There were 26 indicators, and a good sample size range was $80 \leq n \leq 160$. Based on this range, taking into account the available resources, this study determined a sample size of 130 people. This number is considered to be representative of the population (Martínez \& Del Bosque, 2013; Fullerton, 2005).

This study uses mediation analysis in SEM-PLS with the Variance Accounted For (VAF) method starting with testing the significance of the direct effect (service quality on customer loyalty) without including mediating variables (brand image and customer commitment) in the SEM-PLS model. When the direct effect is significant, the work motivation variable is entered into the SEM-PLS model and tested for the indirect effect. If the VAF value is above $80 \%$, it indicates a full mediation role. If the VAF is between $20 \%-80 \%$, it can be categorized as partial mediation. However, if the VAF is less than $20 \%$, there is no mediating effect (Sholihin \& Ratmono, 2021). 


\section{Results and Discussions}

Tabel 2

Respondent characteristic

\begin{tabular}{|c|c|c|c|c|}
\hline No & Respondent Characteristic & Classification & Total & Percentage $\%$ \\
\hline \multirow{3}{*}{1} & \multirow{2}{*}{ Sex } & Male & 73 & 56.2 \\
\hline & & Female & 57 & 43.8 \\
\hline & \multirow[t]{3}{*}{ Total } & & 130 & 100 \\
\hline \multirow{6}{*}{2} & & $17-24$ & 41 & 31.5 \\
\hline & & $25-34$ & 51 & 39.2 \\
\hline & \multirow[t]{3}{*}{ Age (years) } & $35-44$ & 11 & 8.5 \\
\hline & & $45-54$ & 19 & 14.6 \\
\hline & & $>55$ & 8 & 6.2 \\
\hline & \multirow[t]{2}{*}{ Total } & & 130 & 100 \\
\hline \multirow{5}{*}{3} & & Junior High School & 12 & 9.2 \\
\hline & \multirow{3}{*}{ Education } & Senior High School & 64 & 49.2 \\
\hline & & Univesity & 31 & 23.8 \\
\hline & & Others & 23 & 17.7 \\
\hline & \multirow[t]{3}{*}{ Total } & & 130 & 100 \\
\hline \multirow{6}{*}{4} & & Civil Servant & 7 & 5.4 \\
\hline & & Private Employee & 9 & 6.9 \\
\hline & \multirow{3}{*}{ Occupation } & Entrepreneur & 47 & 36.2 \\
\hline & & Student & 43 & 33.1 \\
\hline & & Housewife & 24 & 18.5 \\
\hline & Total & & 130 & 100 \\
\hline
\end{tabular}

Validity testing is a measure of how strong a tool performs its sizing function. Validity test results show that all question items show the value of $r_{\text {count }} \geq r_{\text {tandard }}(0.3)$ at a significance value of 5 percent, it can be explained that all construct indicators in this study are valid and can be used as research instruments.

Table 3

Reability test result

\begin{tabular}{llll}
\hline No & Construct & Cronbach Alpha & Information \\
\hline & & 0,878 & Reliable \\
& & 0,931 & Reliable \\
1 & Service quality & 0,938 & Reliable \\
& & 0,964 & Reliable \\
& & 0,927 & Reliable \\
2 & & 0,975 & Reliable \\
3 & Brand Image & 0,965 & Reliable \\
4 & Customer Commitement & 0,968 & Reliable \\
\hline
\end{tabular}

A reliability test is to measure the consistency of an instrument. The results of the reliability test can be seen in Table 3. Based on Table 3. it can be seen that the Cronbach Alpha of all instruments is greater than 0.6. An indicator of a construct is said to be valid if the cross-loading value of each indicator of the construct in question is greater than the cross-loading of other construct indicators. Table 4. show the Cross Loading result.

Mahatama, A. A. B. P., \& Wardana, M. (2022). The role of brand image and customer commitment in mediating service quality towards customer loyalty. International Research Journal of Management, IT and Social Sciences, 9(1), 79-89. https://doi.org/10.21744/irjmis.v9n1.2006 
Table 4

Cross loading result

\begin{tabular}{|c|c|c|c|c|c|c|c|c|c|c|}
\hline Construct & Indicators & $\begin{array}{r}\text { Service } \\
\text { quality }\end{array}$ & $\begin{array}{l}\text { Physical } \\
\text { evidence }\end{array}$ & Guarantee & Reliability & Concern & $\begin{array}{c}\text { Responsive } \\
\text { ness }\end{array}$ & $\begin{array}{l}\text { Brand } \\
\text { Image }\end{array}$ & $\begin{array}{c}\text { Customer } \\
\text { Commitment }\end{array}$ & $\begin{array}{c}\text { Customer } \\
\text { Loyalty }\end{array}$ \\
\hline \multirow{15}{*}{$\begin{array}{l}\text { Service } \\
\text { quality }\end{array}$} & LPD Kedonganan have a comfortable service roor & 0.800 & 0,901 & 0,734 & 0,757 & 0,746 & 0,715 & 0,731 & 0,724 & 0,755 \\
\hline & LPD Kedonganan have a right room composition & $\mathbf{0 , 8 9 5}$ & 0,933 & 0,839 & 0,853 & 0,858 & 0,821 & 0,854 & 0,865 & 0,875 \\
\hline & LPD Kedonganan staff apperance is neat. & 0,916 & 0.910 & 0,872 & 0,881 & 0,861 & 0,879 & 0,858 & 0,844 & 0,844 \\
\hline & LPD Kedonganan staff put a sympathy on custome & $\mathbf{0 , 8 8 7}$ & 0.828 & 0,927 & 0,851 & 0,818 & 0,837 & 0,842 & 0,804 & 0,809 \\
\hline & I feel safe to make a transaction in LPD Kedongan & 0,906 & 0.823 & 0,958 & 0,869 & 0,834 & 0,869 & 0,877 & 0,872 & 0,863 \\
\hline & I trust LPD Kedonganan. & 0,896 & 0.860 & 0.922 & 0.865 & 0.816 & 0,846 & 0,869 & 0,861 & 0,861 \\
\hline & LPD Kedonganan fullfil their promise & 0,907 & 0.857 & 0.864 & 0.936 & 0.844 & 0,855 & 0,875 & 0,865 & 0,858 \\
\hline & LPD Kedonganan is reliable & 0,928 & 0.871 & 0.878 & 0.953 & 0.866 & 0.890 & 0,886 & 0,879 & 0,878 \\
\hline & LPD Kedonganan give accurate information & 0,901 & 0.846 & 0.860 & 0.937 & 0.853 & 0,831 & 0,859 & 0,851 & 0,844 \\
\hline & LPD Kedonganan quicky respond my request & $\mathbf{0 , 8 8 1}$ & 0.843 & 0,794 & 0,821 & $\mathbf{0 , 9 3 8}$ & 0.840 & 0,847 & 0,822 & 0,854 \\
\hline & LPD Kedonganan provide consultation & $\mathbf{0 , 8 8 8}$ & 0.830 & 0,791 & 0,836 & 0.940 & 0,867 & 0,869 & 0.860 & 0,842 \\
\hline & LPD Kedonganan handle customer wholeheartedly & 0,942 & 0.871 & 0,893 & 0,901 & 0,947 & 0.910 & 0,946 & 0,906 & 0,916 \\
\hline & LPD Kedonganan quickly respond my question & 0,897 & 0.814 & 0.856 & 0.828 & 0.880 & 0,928 & 0,882 & 0,868 & 0.890 \\
\hline & LPD Kedonganan staff pay attention on customer & 0,928 & 0.846 & 0.880 & 0.883 & 0.879 & 0,966 & 0.920 & 0,903 & 0,893 \\
\hline & LPD Kedonganan staff kindly greeting the custome & 0,906 & 0.842 & 0.837 & 0.869 & 0.866 & 0,937 & 0,906 & 0,855 & 0,869 \\
\hline \multirow{4}{*}{$\begin{array}{l}\text { Brand } \\
\text { Image }\end{array}$} & LPD Kedonganan is well-known brand & 0,928 & 0,865 & 0,888 & 0,887 & 0,903 & 0,912 & 0,949 & 0.910 & 0,897 \\
\hline & LPD Kedonganan have a strong attractiveness & 0,887 & 0,809 & 0,837 & 0,843 & 0,888 & 0,882 & $\mathbf{0 , 9 3 1}$ & 0,868 & 0,874 \\
\hline & LPD Kedonganan brand is easy to remember & 0,908 & 0,831 & 0,862 & 0,881 & 0.880 & 0,908 & 0.950 & 0,893 & 0,907 \\
\hline & LPD Kedonganan have a good reputation & 0,931 & 0,871 & 0,895 & 0,892 & 0,898 & 0,914 & 0.950 & 0,916 & 0,927 \\
\hline \multirow{3}{*}{$\begin{array}{l}\text { Customer } \\
\text { Commitment }\end{array}$} & I am emotionally attracted with LPD Kedonganan. & 0,915 & 0.879 & 0.859 & 0.878 & 0.890 & 0,889 & 0,912 & 0,962 & 0,944 \\
\hline & $\begin{array}{l}\text { I have partnership with service provider namely } \\
\text { LPD Kedonganan. }\end{array}$ & 0,915 & 0.852 & 0.882 & 0.887 & 0.880 & 0,892 & 0,922 & 0,968 & 0,924 \\
\hline & $\begin{array}{l}\text { I liked when my personal data are easily identified } \\
\text { by LPD Kedonganan. }\end{array}$ & 0,911 & 0.838 & 0.869 & 0.887 & 0.879 & 0,899 & 0,908 & 0,958 & 0,911 \\
\hline \multirow{4}{*}{$\begin{array}{l}\text { Customer } \\
\text { Loyalty }\end{array}$} & I will continually use LPD Kedonganan service & 0,922 & 0.881 & 0.880 & 0.891 & 0.880 & 0,897 & 0,914 & 0,924 & 0,965 \\
\hline & I will recommend LPD Kedonganan to friend or & 0,879 & 0.830 & 0.831 & 0.828 & 0.860 & 0,871 & 0,901 & 0,887 & 0,941 \\
\hline & $\begin{array}{l}\text { LPD Kedonganan is into consideration when } \\
\text { looking for business partner }\end{array}$ & 0,927 & 0.872 & 0.875 & 0.888 & 0.911 & 0,906 & 0,911 & 0,929 & 0,963 \\
\hline & I refuse any offers from other financial institution & 0,921 & 0.875 & 0.866 & 0.886 & 0.892 & 0,908 & 0,924 & 0,941 & $\mathbf{0 , 9 5 7}$ \\
\hline
\end{tabular}

Based on Table 4. the correlation of service quality construct (X1) with its indicators is higher than the correlation with the indicators of brand image (Y1), customer commitment (Y2), and customer loyalty (Y3). The correlation of brand image constructs (Y1) with its indicators is higher than the correlation with indicators of service quality (X1), customer commitment (Y2), and customer loyalty (Y3). Furthermore, the correlation of the construct of customer commitment (Y2) with its indicators is higher than the correlation with indicators of service quality (X1), brand image (Y1), and customer loyalty (Y3). The correlation of customer loyalty (Y3) with its indicators is higher than the correlation with indicators of service quality (X1), brand image (Y1), and customer commitment (Y2).

Another method to assess discriminant validity is to compare the square root of the average variance extracted $(\sqrt{A V E})$ for each variable with the correlation between construct and other constructs in the model. The model has sufficient discriminant validity if the square root of the AVE for each variable is greater than the correlation between constructs and other constructs in the model (Cossío-Silva et al., 2016; Yee et al., 2010).

Table 5

Square root comparison between average variance extracted with latent variable correlations

\begin{tabular}{|c|c|c|c|c|c|c|c|c|c|c|c|}
\hline \multirow{2}{*}{ Construct } & \multirow{2}{*}{ AVE } & \multirow{2}{*}{$\begin{array}{l}\text { AVE } \\
\text { Root }\end{array}$} & \multicolumn{9}{|c|}{ Correlation } \\
\hline & & & X1.1 & $\mathrm{X} 1.2$ & $\mathbf{X} 1.3$ & X1.4 & $\mathrm{X} 1.5$ & $\mathbf{X 1}$ & Y1 & Y2 & Y3 \\
\hline Physical Evidence (X1.1) & 0.837 & 0.914 & 1.000 & 0.909 & 0.912 & 0.927 & 0.965 & 0.965 & 0.922 & 0.962 & 0.954 \\
\hline Guarantee (X1.2) & 0.876 & 0.935 & 0.884 & 1.000 & 0.920 & 0.879 & 0.936 & 0.958 & 0.927 & 0.949 & 0.904 \\
\hline Reliability (X1.3) & 0.888 & 0.942 & 0.894 & 0.920 & 1.000 & 0.907 & 0.957 & 0.968 & 0.944 & 0.890 & 0.936 \\
\hline Concern (X1.4) & 0.886 & 0.941 & 0.911 & 0.879 & 0.907 & 1.000 & 0.884 & 0.961 & 0.949 & 0.928 & 0.902 \\
\hline Responsiveness (X1.5) & 0.891 & 0.943 & 0.901 & 0.904 & 0.918 & 0.917 & 1.000 & 0.949 & 0.967 & 0.904 & 0.913 \\
\hline Service quality (X1) & 0.808 & 0.898 & 0.890 & 0.958 & 0.968 & 0.961 & 0.909 & 1.000 & 0.954 & 0.918 & 0.926 \\
\hline Brand image (Y1) & 0.893 & 0.944 & 0.954 & 0.902 & 0.913 & 0.926 & 0.912 & 0.954 & 1.000 & 0.917 & 0.962 \\
\hline Customer commitment (Y2) & 0.927 & 0.962 & 0.904 & 0.922 & 0.927 & 0.944 & 0.927 & 0.967 & 0.893 & 1.000 & 0.954 \\
\hline Customer loyalty (Y3) & 0.915 & 0.956 & 0.893 & 0.894 & 0.911 & 0.901 & 0.928 & 0.954 & 0.957 & 0.949 & 1.000 \\
\hline
\end{tabular}


Based on Table 5. it can be concluded that the AVE root value of the service quality construct (X1) is 0.898 , greater than the correlation between latent variables and other constructs besides service quality (X1). The AVE root value of the physical evidence construct $(\mathrm{X} 1.1)$ is 0.914 , greater than the correlation between latent variables and other constructs besides physical evidence (X1.1). The AVE root value of the Guarantee construct (X1.2) is 0.935 , greater than the correlation between the latent variables and other constructs besides the Guarantee (X1.2). The root value of the reliability construct AVE (X1.3) is 0.942, greater than the correlation between latent variables and other constructs besides reliability (X1.3). The AVE root value of the caring construct (X1.4) is 0.941, greater than the correlation between latent variables and other constructs besides caring (X1.4). The root value of the responsiveness construct AVE (X1.5) is 0.943, greater than the correlation between latent variables and other constructs besides responsiveness (X1.5). The AVE root value of the brand image construct (Y1) is 0.944, greater than the correlation between latent variables and other constructs besides brand image (Y1). Furthermore, the AVE root value of the customer commitment construct (Y2) is 0.962 , which is greater than the correlation between latent variables and other constructs besides customer commitment (Y2). The AVE root value of the customer loyalty construct (Y3) is 0.956 , greater than the correlation between latent variables and other constructs besides customer loyalty (Y3).

Hypothesis testing regarding the role of brand image and customer commitment in mediating the effect of service quality on customer loyalty be seen in Table 5. and Figure 2. as follows:

Table 6

Path coefficients

\begin{tabular}{|c|c|c|c|c|c|c|}
\hline \multicolumn{2}{|r|}{ Construct } & \multirow{2}{*}{$\begin{array}{c}\begin{array}{c}\text { Correlation } \\
\text { Coef. }\end{array} \\
0,243\end{array}$} & \multirow{2}{*}{$\begin{array}{c}\begin{array}{c}\text { Std. } \\
\text { Error }\end{array} \\
0,119\end{array}$} & \multirow{2}{*}{\begin{tabular}{|c|}
$\boldsymbol{t}$ Statistics \\
2,043 \\
\end{tabular}} & \multirow{2}{*}{$\begin{array}{c}\boldsymbol{p} \text { Values } \\
0,042 \\
\end{array}$} & \multirow{2}{*}{$\begin{array}{c}\text { Information } \\
\text { Significant } \\
\end{array}$} \\
\hline Service quality (X1) & $\rightarrow$ Customer loyalty (Y3) & & & & & \\
\hline Service quality (X1) & $\rightarrow$ Brand image (Y1) & 0,967 & 0,005 & 196,907 & 0,000 & Significant \\
\hline Service quality (X1) & $\rightarrow$ Cust. commitment (Y2) & 0,949 & 0,007 & 127,266 & 0,000 & Significant \\
\hline Brand image $(\mathrm{Y} 1)$ & $\rightarrow$ Customer loyalty (Y3) & 0,248 & 0,149 & 1,667 & 0,096 & Not significant \\
\hline Cust. Commitment ( & $Y 2) \rightarrow$ Customer loyalty (X1) & 0,497 & 0,106 & 4,707 & 0,000 & Significant \\
\hline
\end{tabular}

Table 6. shows that the direct effect of each variable. It shows that there is a significant direct effect of service quality on customer loyalty, service quality to brand image, service quality to customer commitment, and customer commitment to customer loyalty. It also shows that brand image does not significantly have a direct effect on customer loyalty (Darmayasa \& Yasa, 2021; Devi \& Yasa, 2021).

Table 7

Indirect effect and VAF calculation of brand image

\begin{tabular}{|c|c|c|c|c|}
\hline \multirow{2}{*}{\multicolumn{2}{|c|}{ Variabel }} & \multicolumn{3}{|c|}{ Indirect effect } \\
\hline & & \multirow{2}{*}{$\frac{\text { Coef. }}{0.239}$} & \multirow{2}{*}{$\begin{array}{c}\boldsymbol{t} \text { Statistics } \\
1,663\end{array}$} & \multirow{2}{*}{$\begin{array}{c}\boldsymbol{p} \text { Values } \\
0,097\end{array}$} \\
\hline Service quality & $\rightarrow$ Brand Image $\rightarrow$ Customer Commitment & & & \\
\hline \multicolumn{5}{|c|}{ Variabel } \\
\hline Service quality & $\rightarrow$ Brand Image $\rightarrow$ Customer Commitment & 0.248 & 1.667 & 0.096 \\
\hline \multicolumn{5}{|c|}{ VAF } \\
\hline indirect effect / & total effect $(0,239 / 0,248)$ & 0,963 & & \\
\hline
\end{tabular}

Based on data presented in Table 7. brand image as a mediating variable has a VAF value of 0.969 (96.3\%), it can be concluded that brand image has a fully mediating role in the relationship between the influence of service quality on customer loyalty

Mahatama, A. A. B. P., \& Wardana, M. (2022). The role of brand image and customer commitment in mediating service quality towards customer loyalty. International Research Journal of Management, IT and Social Sciences, 9(1), 79-89. https://doi.org/10.21744/irjmis.v9n1.2006 
Table 8

Indirect effect and VAF calculation of customer commitmet

\begin{tabular}{|c|c|c|c|c|c|}
\hline \multirow{2}{*}{\multicolumn{3}{|c|}{ Variabel }} & \multicolumn{3}{|c|}{ Indire ct effect } \\
\hline & & & \multirow{2}{*}{$\begin{array}{c}\text { Coef. } \\
0,472\end{array}$} & \multirow{2}{*}{$\begin{array}{c}\text { t Statistics } \\
4,712\end{array}$} & \multirow{2}{*}{$\frac{p \text { Values }}{0,000}$} \\
\hline Service quality & $\rightarrow$ Customer commitment & $\rightarrow$ Customer loyalty & & & \\
\hline \multicolumn{6}{|c|}{ Variabel } \\
\hline Service quality & $\rightarrow$ Customer commitment & $\rightarrow$ Customer loyalty & 0.497 & 4.707 & 0,000 \\
\hline \multicolumn{3}{|c|}{ VAF } & & & \\
\hline indirect effect $/$ & total effect( $0,472 / 0,497)$ & & $\mathbf{0 , 9 5 0}$ & & \\
\hline
\end{tabular}

Based on the data presented in Table 8. customer commitment as a mediating variable has a VAF of 0.950 (95.0\%). So it can be concluded that customer commitment has a fully mediating role in the relationship between service quality and customer loyalty (Giovanis et al., 2014; Auh et al., 2007).

\section{Conclusion}

Based on the research results it can be explained that the influence of the exogenous construct (X) which consists of service quality on the endogenous construct (Y), namely brand image, customer commitment, and customer loyalty, are as follows. The estimation results of the structural model as presented in Table 6. show that hypothesis testing on the effect of service quality on customer loyalty produces a correlation coefficient of 0.243 . The value of $t$ statistics obtained is 2.043 and the value of $\mathrm{p}$ values is $0.042(<0.05)$. These results indicate that service quality has a positive and significant effect on customer loyalty.

The estimation results of the structural model as presented in Table 6. show that hypothesis testing on the effect of service quality on a brand image produces a correlation coefficient value of 0.967 . The value of $t$ statistics is 196.907 and the value of $\mathrm{p}$ values is $0.000(<0.05)$. These results indicate that service quality has a positive and significant effect on brand image. The estimation results of the structural model as presented in Table 6 . show that hypothesis testing on the influence of customer quality on customer commitment produces a correlation coefficient value of 0949. The t-Statistics value is 127.266 and the $p$-value is $0.000(<0.05)$. These results indicate that service quality has a positive and significant effect on customer commitment.

The estimation results of the structural model as presented in Table 6. show that the effect of brand image on customer loyalty produces a correlation coefficient of 0.248 . The value of t Statistics is 1.667 and the value of $p$ values is $0.096(<0.05)$. This shows that brand image has a positive and significant effect on customer loyalty. The estimation results of the structural model as presented in Table 6. show that hypothesis testing on the effect of customer commitment on customer loyalty produces a correlation coefficient value of 0.497 . The value of t Statistics is 4.707 and the value of $\mathrm{p}$ values is $0.000(<0.05)$. These results indicate that customer commitment has a positive and significant effect on customer loyalty.

The estimation results of the structural model presented in Table 7. show that hypothesis testing of the brand image mediates the effect of service quality on customer loyalty produces a correlation coefficient value of 0.239 . The value of $t$ statistics is 1.663 and the p-value is $0.097(<0.05)$. These results indicate that brand image mediates the effect of service quality on customer loyalty. The estimation results of the structural model presented in Table 8 . show that the hypothesis testing of customer commitment mediates the effect of service quality on customer loyalty resulting in a correlation coefficient of 0.472 . The value of t statistics is 4.712 and the p-value is $0.000(<0.05)$. These results indicate that customer commitment mediates the effect of service quality on customer loyalty.

In order to increase customer loyalty, LPD Kedonganan needs to improve their service quality continually by giving excellent service, quick and accurate responses, having empathy, and always listening to customers regarding the LPD performance. Commitment can also be interpreted as a customer's desire that lasts for a long time to maintain a profitable relationship with the company. In addition, things that need to be considered are also continuing to develop other offices around the Kedonganan village so that all communities can be served so that later it will be able to increase customer loyalty at the LPD Kedonganan. 
Conflict of interest statement

The authors declared that's they have no competing interests.

Statement of authorship

The authors have a responsibility for the conception and design of the study. The authors have approved the final article.

Acknowledgments

We are grateful to two anonymous reviewers for their valuable comments on the earlier version of this paper.

Mahatama, A. A. B. P., \& Wardana, M. (2022). The role of brand image and customer commitment in mediating service quality towards customer loyalty. International Research Journal of Management, IT and Social Sciences, 9(1), 79-89. https://doi.org/10.21744/irjmis.v9n1.2006 


\section{References}

Akroush, M. N., Dawood, S. A., \& Affara, I. B. (2015). Service quality, customer satisfaction and loyalty in the Yemeni mobile service market. International Journal of Services, Economics and Management, 7(1), 53-73.

Al-Hawari, M. A. (2011). Automated service quality as a predictor of customers' commitment: a practical study within the UAE retail banking context. Asia Pacific Journal of Marketing and Logistics.

Aryani, D., \& Rosinta, F. (2011). Pengaruh kualitas layanan terhadap kepuasan pelanggan dalam membentuk loyalitas pelanggan. BISNIS \& BIROKRASI: Jurnal Ilmu Administrasi dan Organisasi, 17(2).

Auh, S., Bell, S. J., McLeod, C. S., \& Shih, E. (2007). Co-production and customer loyalty in financial services. Journal of retailing, 83(3), 359-370. https://doi.org/10.1016/j.jretai.2007.03.001

Caceres, R. C. \&amp; Paparoidamis, NG (2007). Service quality, relationship satisfaction, trust, commitment and business-to-business loyalty. European Journal of Marketing, 41(7/8).

Čater, T., \& Čater, B. (2010). Product and relationship quality influence on customer commitment and loyalty in B2B manufacturing relationships. Industrial Marketing Management, 39(8), 1321-1333. https://doi.org/10.1016/j.indmarman.2010.02.006

Chen, M., Zhou, J., \& Li, T. (2008, October). The impact of service quality and relationship quality on E-shop brand image. In 2008 IEEE International Conference on Service Operations and Logistics, and Informatics (Vol. 1, pp. 89-92). IEEE.

Chen, S. C. (2015). Customer value and customer loyalty: Is competition a missing link?. Journal of retailing and consumer services, 22, 107-116. https://doi.org/10.1016/j.jretconser.2014.10.007

Chinomona, R. (2016). Brand communication, brand image and brand trust as antecedents of brand loyalty in Gauteng Province of South Africa. African Journal of Economic and Management Studies.

Cossío-Silva, F. J., Revilla-Camacho, M. Á., Vega-Vázquez, M., \& Palacios-Florencio, B. (2016). Value co-creation and customer loyalty. Journal of Business Research, 69(5), 1621-1625. https://doi.org/10.1016/j.jbusres.2015.10.028

Darmayasa, G. N. A. R., \& Yasa, N. N. K. (2021). The influence of relationship marketing on customer loyalty: Customer satisfaction as a mediation variable. International Research Journal of Management, IT and Social Sciences, 8(6), 648-660. https://doi.org/10.21744/irjmis.v8n6.1963

Dash, S., Bruning, E., \& Guin, K. K. (2009). A cross-cultural comparison of individualism's moderating effect on bonding and commitment in banking relationships. Marketing Intelligence \& Planning.

Devi, A. A. D. T., \& Yasa, N. N. K. (2021). The role of customer satisfaction in mediating the influence of service quality and perceived value on brand loyalty. International Research Journal of Management, IT and Social Sciences, 8(3), 315-328. https://doi.org/10.21744/irjmis.v8n3.1786

Dewi, M. R., Yadnya, I. P., \& Sudiartha, G. M. (2017). Pengaruh Dana Pihak Ketiga, Loan To Deposit Ratio Dan Rentabilitas Terhadap Kredit LPD Kabupaten Badung (Doctoral dissertation, Udayana University).

Fikri, S., Wiyani, W., \& Suwandaru, A. (2016). Pengaruh Kualitas Pelayanan Terhadap Kepuasan Dan Loyalitas Mahasiswa (Studi pada Mahasiswa Strata I Fakultas Ilmu Sosial dan Ilmu PolitikUniversitas Merdeka Malang). Jurnal bisnis dan manajemen, 3(1).

Fullerton, G. (2005). The service quality-loyalty relationship in retail services: does commitment matter?. Journal of Retailing and Consumer Services, 12(2), 99-111. https://doi.org/10.1016/j.jretconser.2004.04.001

Fullerton, G. (2014). The moderating effect of normative commitment on the service quality-customer retention relationship. European journal of marketing.

Gede, M. Y. B. I., \& Sumaedi, S. (2013). An analysis of library customer loyalty. Library Management, 34(6/7), 397414.

Ghani, E. K., Jamal, J., Puspitasari, E., \& Gunardi, A. (2018). Factors influencing integrated reporting practices among Malaysian public listed real property companies: A sustainable development effort. International Journal of Managerial and Financial Accounting, 10(2), 144-162.

Giovanis, A. N., Zondiros, D., \& Tomaras, P. (2014). The antecedents of customer loyalty for broadband services: The role of service quality, emotional satisfaction and corporate image. Procedia-Social and Behavioral Sciences, 148 , 236-244. https://doi.org/10.1016/j.sbspro.2014.07.039

Hamel, G., \& Prahalad, C. K. (2000). Kompetisi Masa Depan; Strategi-Strategi Terobosan untuk Merebut Kendali atas Industri Anda dan Menciptakan Pasar Masa Depan. Jakarta: Binarupa.

Hazra, S. G., \& Srivastava, K. B. (2009). Impact of Service Quality on Customer Loyalty, Commitment and Trust in the Indian Banking Sector. IUP Journal of Marketing Management, 8. 
Izogo, E. E. (2017). Customer loyalty in telecom service sector: the role of service quality and customer commitment. The TQM Journal.

Jahanzeb, S., Fatima, T., \& Butt, M. M. (2013). How service quality influences brand equity: The dual mediating role of perceived value and corporate credibility. International Journal of Bank Marketing.

Kusuma, E. C. (2018). Pengaruh Nilai Yang Diterima Pelanggan Dan Kualitas Pelayanan Terhadap Loyalitas Pelanggan: Kepuasan Pelanggan Sebagai Mediator Dan Gender Sebagai Moderator. Jurnal bisnis dan Manajemen, 5(1).

Kwon, W. S., \& Lennon, S. J. (2009). What induces online loyalty? Online versus offline brand images. Journal of Business Research, 62(5), 557-564. https://doi.org/10.1016/j.jbusres.2008.06.015

Laemonta, J. H., \& Padmalia, M. (2016). Pengaruh Inovasi dan Kualitas Layanan terhadap Loyalitas Konsumen Terang Bulan-Martabak 93. Jurnal Entrepreneur dan Entrepreneurship, 5(2), 73-80.

Levy, S., \& Hino, H. (2016). Emotional brand attachment: a factor in customer-bank relationships. International Journal of Bank Marketing.

Martínez, P., \& Del Bosque, I. R. (2013). CSR and customer loyalty: The roles of trust, customer identification with the company and satisfaction. International Journal of Hospitality Management, 35, 89-99. https://doi.org/10.1016/j.ijhm.2013.05.009

Moorman, C., \& Deshpande, R. Zaltman (1993),"Factors Affecting Trust in Market Relationships,”. Journal of Marketing, 57, 81-101.

Mukerjee, K. (2018). The impact of brand experience, service quality and perceived value on word of mouth of retail bank customers: Investigating the mediating effect of loyalty. Journal of Financial Services Marketing, 23(1), 1224.

Nyadzayo, M. W., \& Khajehzadeh, S. (2016). The antecedents of customer loyalty: A moderated mediation model of customer relationship management quality and brand image. Journal of retailing and consumer services, 30, 262270. https://doi.org/10.1016/j.jretconser.2016.02.002

Oliver, R. (1999). L.(1999). Whence consumer loyalty. Journal of marketing, 63(4), 33-44.

Parasuraman, A., Zeithaml, V. A., \& Berry, L. (1988). SERVQUAL: A multiple-item scale for measuring consumer perceptions of service quality. 1988, 64(1), 12-40.

Parawansa, D. A. S. (2018). Effect of commitment and customers' satisfaction on the relationship between service quality and customer retention in rural banks in Makassar, Indonesia. Journal of Management Development.

Purwaningsih, R., \& Kusuma, P. D. (2015). Analisis Faktor-Faktor Yang Mempengaruhi Kinerja Usaha Kecil Dan Menengah (UKM) Dengan Metode Structural Equation Modeling (Studi kasus UKM berbasis Industri Kreatif Kota Semarang). Prosiding SNST Fakultas Teknik, 1(1).

Quach, T. N., Jebarajakirthy, C., \& Thaichon, P. (2016). The effects of service quality on internet service provider customers' behaviour: A mixed methods study. Asia Pacific Journal of Marketing and Logistics.

Rather, R. A., \& Sharma, J. Y. O. T. I. (2016). Customer engagement in strengthening customer loyalty in hospitality sector. South Asian Journal of Tourism and Heritage, 9(2), 62-81.

Saputra, F. I. (2013). Kualitas Layanan, citra dan pengaruhnya terhadap loyalitas melalui kepuasan pelanggan (studi pada PT Bank Bni 46 sentra kredit kecil Surabaya). Jurnal aplikasi manajemen, 11(3), 445-457.

Sholihin, M., \& Ratmono, D. (2021). Analisis SEM-PLS dengan WarpPLS 7.0 untuk Hubungan Nonlinier dalam Penelitian Sosial dan Bisnis. Penerbit Andi.

Sumertana, I. W., Nuridja, I. M., \& Meitriana, M. A. (2016). Pengaruh Kualitas Pelayanan terhadap Loyalitas Pelanggan dengan Kepuasan Pelanggan sebagai Variabel Intervening pada Water Park Seririt Singaraja Tahun 2014-2015. Jurnal Pendidikan Ekonomi Undiksha, 7(2).

Tahun, R. A., Bunga, M., \& Nyoko, A. E. (2018). Pengaruh Kepercayaan dan Komitmen Terhadap Loyalitas Nasabah Pada Bank Perkreditan Rakyat Tanaoba Lais Manekat Kota Kupang. Journal of Management: Small and Medium Enterprises (SMEs), 7(2), 147-165.

Yee, R. W., Yeung, A. C., \& Cheng, T. E. (2010). An empirical study of employee loyalty, service quality and firm performance in the service industry. International Journal of Production Economics, 124(1), 109-120. https://doi.org/10.1016/j.ijpe.2009.10.015

Mahatama, A. A. B. P., \& Wardana, M. (2022). The role of brand image and customer commitment in mediating service quality towards customer loyalty. International Research Journal of Management, IT and Social Sciences, 9(1), 79-89. https://doi.org/10.21744/irjmis.v9n1.2006 